811.163.41'367

$81^{\prime} 42$

811.163.41:316.774

https://doi.org/10.18485/sj.2021.26.1.5

БИЉАНА М. МИШИЋ ИЛИЋ*

АНА М. КРСТИТ

Универзитет у Нишу

Филозофски факултет
Оригинални научни рад

Примљен: 13. 10. 2020.

Прихваћен: 12. 1. 2021.

\title{
ДЕАГЕНТИЗАЦИЈА У ИЗЈАВАМА КРИЗНОГ ШТАБА ПОВОДОМ ПАНДЕМИЈЕ ВИРУСА КОВИД-19 У СРБИЈИ
}

У раду се истражује дискурсна стратегија деагентизације, реализована употребом неколико синтаксичких конструкција (пасиви без агенса, обезличене конструкције, номинализација), у изјавама чланова Кризног штаба које су пренете у српским медијима поводом пандемије вируса ковид-19. Квалитативном анализом примера испитују се не само могуће корелације између синтаксичких и лексичких избора већ и дискурсни контекст који одређује избор и комбинацију језичких средстава. Резултати се могу интерпретирати у светлу критичке анализе дискурса као дискурсна стратегија деагентизације, односно свесни и конвенционализовани избори језичких конструкција и њихових комбинација у циљу мистификације информација и манипулације јавности у посебно осетљивим друштвеним околностима.

Кључне речи: критичка анализа дискурса, агентивност, деагентизација, пасивизација, номинализација, обезличене конструкције, српски језик, Кризни штаб. 


\section{1. УВОД}

Предмет овог рада је дискурсна стратегија деагентизације у директним изјавама чланова Кризног штаба ${ }^{1}$ поводом пандемије вируса короне у Србији, пренетим у медијима у периоду од средине марта до октобра 2020. године. Рад се бави одређеним синтаксичким конструкцијама којима се остварује деагентизација, у циљу да се испитају могуће корелације између синтаксичких и лексичких избора и дискурсног контекста који одређује избор и комбинацију језичких средстава. Уз дескриптивну формално-текстуалну анализу карактеристичних примера из корпуса, примери се интерпретирају и у светлу критичке анализе дискурса, као синтаксички реализована дискурсна стратегија деагентизације, коју говорници користе а медији преносе са могућом намером манипулације јавног мњења у посебно осетљивим друштвеним и политичким околностима. Након уводног дела, рад је подељен на теоријски преглед и емпиријску анализу, у коме су посебно разматране следеће синтаксичке конструкције: партиципски пасив, рефлексивни пасив, обезличене конструкције, номинализација, као и комбинација ових конструкција.

\section{2. ПОЈАМ ДЕАГЕНТИЗАЦИЈЕ И СИНТАКСИЧКЕ КОНСТРУКЦИЈЕ КОЈИМА СЕ ОНА РЕАЛИЗУЈЕ У СРПСКОМ ЈЕЗИКУ}

Теоријски оквир овог истраживања чине радови из области критичке анализе дискурса, нарочито они који се баве дискурсним стратегијама, као и србистичка граматичка литература која разматра синтаксичке конструкције које су у овом раду идентификоване као језичка средства за реализацију дискурсне стратегије деагентизације.

2.1. Феномен деагентизащије, који је предмет овог рада, непосредно је везан за појам агентивности, који се у лингвистици, у ужем смислу, везује за семантичке улоге реченичних конституената и, конкретно, за улогу агенса. Типично, агенс је свесни вршилац радње, који делује вољно или са намером и врши неку радњу која има физичке, видљиве последице, а по синтаксичкој функцији је граматички субјект активне клаузе. Међутим, агенс може бити изражен и лексикализован неком врстом метонимијског трансфера и/или потиснут из положаја граматичког субјекта, 'замагљен' неком синтаксичком конструкцијом. У нешто ширем смислу, у друштвено оријентисаним лингвистичким гранама, као што су прагматика, социолингвистика, критичка анализа дискурса и антрополошка лингвистика, појам агентивности укључује и

${ }^{1}$ Влада Републике Србије је 13. марта 2020. године донела Закључак о образовању Кризног штаба за сузбијање заразне болести ковид-19. Наведеним актом утврђен је задатак Кризног штаба за сузбијање ове заразне болести као и њен састав. 
јаку евалуативну компоненту, што може бити од значаја у анализи феномена агентивности у медијском дискурсу. ${ }^{2}$

Деагентизација се може примарно посматрати на лексичко-граматичком нивоу као конструисање језичког исказа на такав начин да семантичка категорија агенса (са основним семантичким карактеристикама људско и свесно) бива изостављена и као синтаксички конституент и као семантичка улога. На синтаксичком плану, типичан експонент деагентизације су пасивне реченице без исказаног агенса, различите безличне конструкције и номинализације, док се на семантичком плану може говорити о представљању пропозиције као догађаја или појаве која се одвија сама по себи, или као уобичајени и природан ток ствари. Занимљив предлог о деагентивности као могућој широј функционално-семантичкој категорији, која укључује све синтаксичке конструкције у којима је агенс са семантичке равни дијатезе реченице уклоњен са њене синтаксичке равни, даје Д. Сааведра, истичући да би таква категорија могла помоћи у „савладавању неусаглашености критерија за дефинирање једне синтаксичке конструкције као пасивне, обезличене (пасивно-безличне) или безличне" (Саведра 2009: 69).

Такође, деагентизација се може посматрати из угла анализе дискурса и прагматике као дискурсна стратегија којом се дискурсне радње интенционално представљају као нешто што нема узрок у свесном људском агенсу већ се дешавају саме од себе, као догађаји (Ван Лувен 2008: 66-68). У критичкој анализи дискурса дискурсне стратегије заузимају битно место, а најопштије се дефинишу као "a more or less intentional plan of practices (including discursive practices) adopted to achieve a particular social, political, psychological or linguistic aim” (Водак 2001: 73). Према утицајној класификацији Ван Левена (2008), деагентизација је једна од стратегија представљања друштвених учесника у дискурсним радњама (social actor representation strategy).

Критичка анализа дискурса (КАД) као широка и разноврсна теоријска оријентација дискурс посматра као облик друштвене праксе и посматра га као текст (производ), као интеракцију (процеси стварања и интерпретације текста) и као контекст (друштвени услови стварања и интерпретације). КАД тежи да открије како се текстови конструишу тако да се одређени (и потенцијално индоктринирајући или манипулативни) аспекти изразе на прикривен и суптилан начин. ${ }^{3}$ Управо имајући у виду друштвени контекст комуникације текстова

${ }^{2}$ Детаљније о агентивности, а посебно у медијском дискурсу у Мишић Илић (2018). Напоменимо још да се термини 'агенс' и 'агентивност' могу користити не само у уском смислу семантичке улоге и не само за материјалне процесе вршења радње већ и тамо где би се у неким теоријским описима (рецимо, генеративна или системско-функционална граматика), користили семантички специфичнији термини (говорник, доживљавач, носилац односа и слично) када се ради о 'активним' учесницима у другим типовима процеса, односно ситуација реализованих неким језичким исказом.

${ }^{3}$ Детаљније у Ферклаф 1992, Ферклаф 1995, Ферклаф 2001, Батстон 1995. 
(изјаве Кризног штаба) које су предмет овог рада, испитивање феномена деагентизације и синтаксичких конструкција којима се реализује укључује дискурсно-критичкоаналитички, а не само синтаксичко-семантички аспект. О месту синтаксе у КАД, са посебним освртом на синтаксичке конструкције у енглеском и српском, од којих су неке и предмет овог рада, детаљније у Мишић Илић (2011). Када се ради о критичкој компоненти, КАД проучава дискурс у датом контексту и тежи да утврди како су одређени елементи у дискурсу истакнути, одабрани, или пак замаскирани да би се постигао неки идеолошки ефекат, или једноставно ефекат манипулације (Ферклаф 1992: 196). Није изненађујуће да је у КАД најчешћи предмет анализе и критике управо политички дискурс. То може подразумевати дискурс који јесте из домена политике, или, пак, дискурс из неке области друштвене делатности (Вилсон 2003: 398). Стога треба истаћи да политички дискурс могу производити и људи који се не баве нужно политиком, али је он изнесен са политичким тенденцијама и својеврсном идеологијом. Дискурс који је предмет наше анализе управо се у том смислу може сматрати погодним за анализу, иако се примарно тиче здравља нације у пандемији и акција које предузимају чланови овлашћеног тела, Кризног штаба, и надлежних структура власти. Дискурс, и конкретно дискурс који смо анализирали, представља тип жанра, односно институционализованог модела размишљања и друштвене праксе, а они који га конструишу не посматрају се као индивидуе већ као представници одређене дискурсне заједнице (Видовсон 2007: 70). Задатак КАД је да открије трагове идеолошких склоности у таквим текстовима, при чему преиспитује идеје и претпоставке тих дискурсних заједница које се приказују као статус кво заједнице, а заправо су прикривено одраз неједнакости у друштву и истицања политичке надмоћи елитне групе на рачун свих осталих (Видовсон 2007: 71). Ипак, овако широко схваћен задатак излази из оквира овога рада, који је примарно лингвистички и синтаксички оријентисан.

У вези са конкретним истраживањима дискурса везаним за пандемију ковида-19, истакли бисмо да је у социо-когнитивном моделу КАД започето компаративно међународно истраживање (Кранерт и др. 2020), у циљу да се истраже дискурсивна и језичка средства којима се пандемија као макродогађај преноси у локалне средине, на корпусу изјава водећих политичара у 29 земаља, укључујући и Србију. Фокус истраживања је био на представљању различитих група - унутрашњи круг, сродне групе и они споља. Док је углавном свуда сам вирус представљен као главни представник спољне, непријатељске групе, у различитим земљама постоје разлике у представљању унутрашњег круга и сродних група, у зависности од друштвеног и политичког контекста.

Следи кратак преглед синтаксичких конструкција у српском језику којима се реализује дискурсна стратегија деагентизације.

2.2. О пасиву се у српском језику традиционално говорило искључиво кроз призму морфологије, односно глаголске парадигме, па је његово син- 
таксичко испољавање остајало недовољно истражено. Пасивом као врстом глаголске дијатезе која се јавља као опозиција активу у оквиру категорије прелазних глагола детаљно се бавио Танасић $(2005,2014)$, који је уз бројна запажања и формализације пасивних конструкција дао и следеће, које је релевантно за нашу анализу примера: „У пасивној реченици није обавезно исказивање агенса, али он обавезно учествује у ситуацији која се представља пасивном дијатезом. Пасивна конструкција карактерише се компонентом динамичности (Д), тј. вршење радње је актуелно у моменту о коме реферише пасивна реченица" (Танасић 2014: 12).

Пасив представља механизам деагентивности којим се објекат из активне реченице, односно пацијенс, доводи у позицију носиоца реченичне информације, док вршилац радње може а и не мора бити исказан, као што је случај у нашим анализираним примерима.

Литература разликује две основне конструкције које исказују пасивно значење у српском језику - партиципски пасив и рефлексивни, тј. се пасив. Ако постоји потреба за исказивањем агенса, онда се то чини агентивном одредбом од (стране) + именичка фраза у генитиву (Станојчић/Поповић 2002: 253). Исказивање агенса на овај начин, нарочито ако је институционалног карактера, чешће се јавља у административном стилу (Пипер и др. 2005: 625). За разлику од партиципског пасива, рефлексивни, односно се пасив настаје удруживањем партикуле се и активног облика глагола.

Заједничка карактеристика партиципског и рефлексивног пасива је хомонимичност, тачније ни једна ни друга конструкција нису резервисане само за изражавање пасивног значења. Како наводи Танасић (2014: 222-225), код партиципског пасива, односно пасива са трпним придевом, хомонимичност се огледа у двојакој природи самог трпног придева, који има глаголску и придевску компоненту, те се реченица интерпретира у зависности од тога која компонента је у првом плану, а која је потиснута. Код рефлексивног пасива, хомонимија настаје када не можемо да одредимо да ли је се део рефлексивног глагола у предикату или се ради о прелазном глаголу где је се показатељ пасивне дијатезе.

Новија србистичка литература (Танасић 2005, 2014; Саведра 2010), поред ове две уобичајене пасивне конструкције наводи још неколико мање фреквентних врста, синтаксичке и семантичке разлике и сличности међу њима, као и разлоге морфосинтаксичке и лексикосемантичке природе који могу утицати на избор конкретне пасивне конструкције.

2.3. Безличне и обезличене конструкције представљају широку категорију око које у литератури нема увек потпуног слагања у томе шта су карактеристичне одлике и шта све може спадати у коју врсту. У односу на пасив значајна је дистинкција коју прави Танасић: реченице са безличном конструкцијом формирају се од личних глагола у чијем значењу се подразумева постојање 
вршиоца радње. У овим реченицама подразумева се уопштени колективни вршилац радње (Увече се седело пред капијом : Људи су увече седели пред капијом). Реченице са безличном конструкцијом су обезличена варијанта субјекатско-предикатске реченице. 'Обезличене' су тиме што нема субјекта (а глагол подразумева вршиоца радње) и што је глагол у неутралном, безличном облику 3. л. једнине средњег рода. То их чини сличним са безличним реченицама па отуда и назив обезличене реченице. Танасић (2018: 413) наводи битну разлику између ових реченица и пасивних (обезличена пасивна конструкција) и да се разликују по томе што се обезличене не образују искључиво од прелазних глагола, или, када се образују, врши се неутрализација; субјекат је блокиран и на морфолошком плану глагол је обезличен. Заједничко им је то што је валенција за агентивну допуну слаба. Мишић Илић (2011: 100) напомиње да прагматички и дискурсно посматрано, нема много разлике између ове две конструкције, што ће бити показано и у анализи примера.

Још једна врста безличних конструкција која се помиње у литератури као релевантна за деагентивност су и безличне конструкције са рефлексивном заменицом се, које су честе са глаголима који изражавају вербалну комуникацију, мишљење и уверење. Танасић (2005: 197-210) овакве реченице назива безличним са уопштеним агенсом. Постојање агенса се подразумева, али се он не исказује експлицитно. Уколико се ради о глаголима вербалне комуникације, зависна допунска клауза може бити врста директног или индиректног говора. Оваквом конструкцијом се упадљиво избегава помињање извора информације исказане зависном клаузом, чиме се скида одговорност и са онога ко саопштава информацију и са онога ко је информацију први изрекао (Мишић Илић 2011: 100).

О функционалној сличности неколико типова обезличених (имперсоналних) конструкција и партиципског пасива писала је Московљевић Поповић (2018a, 2018б), залажући се, из општелингвистичке перспективе, за преиспитивање подврста категорије пасива у постојећем синтаксичком опису српског језика. Уочивши да имперсоналне реченичне структуре с партиципским пасивом формиране с допуном у инструменталу NPins (типа Баратано је подацима за које нико није чуо) и имперсоналне реченичне структуре с партиципским пасивом формиране од глагола комуникације и когнитивних процеса с допуном у облику предлошко-падежне конструкције „о” + NPloc (типа Ha cacmaнкy није дискутовано о том проблему) имају бројне сличности са пасивним партиципским конструкцијама од транзитивних глагола, и анализиравши их по одређеним ширим лингвистичким критеријумима, Московљевић Поповић (2018a: 175, 20186: 243-244) предлаже да се ове конструкције класификују не само као имперсоналне већ да се уведе нова категорија - имперсонални перифрастични пасив. Из дискурсно-функционалне перспективе, посебно је значајно запажање да је код ових конструкција „доминантна функција прикривања или 
потискивања (демоције) агенса, његова анонимизација и деиндивидуализација и истовремено истицање у први план другог семантичког аргумента предиката, теме”, као и да по својим дистрибуционим и функционалним карактеристикама у великој мери кореспондирају с пасивним реченицама формираним од транзитивних глагола (Московљевић Поповић 2018б: 242).

2.4. Под номинализацијом се у најопштијем смислу подразумева коришћење номиналне форме (глаголске именице или неке именице парадигматски повезане са одговарајућим глаголом, која може бити употребљена самостално или у предлошко-падежним синтагмама) да би се енкодирао неки процес (радња, стање, догађај, однос), што се, иначе, типично чини глаголима (Мишић Илић 2011: 101).

О номинализацији у србистичкој литератури значајни су синтаксички радови М. Радовановића, који је у складу са генеративном школом посматра као процес кондензације, уочавајући да је она испољена на површинској структури. Он издваја два типа номиналних форми, при чему је први непосредно изведен из дубинског семантичког еквивалента (девербативне именице, девербативни придеви, деадјективне именице, инфинитив, партицип), и други, који није непосредно изведен из дубинског семантичког еквивалента (Радовановић 1990: 16). Међутим, иако аутор запажа да је номинализација погодна и карактеристична за одређене функционалне стилове (новинарски, административни, научни, итд.), јер је њихова тематика уопштена и апстрактна, нема много коментара о дискурсним ефектима. О номинализацији у хрватском језику занимљиво запажање износи Белај (2002) који је доводи у везу са пасивом, и за разлику од правог, граматичког пасива, номинализацију сматра лексичким пасивом и издваја пет структурних типова. Иако се неке од наведених конструкција у хрватском разликују од сличних у српском, па примере нисмо анализирали по овом моделу, значајна је уочена сличност на семантичком и дискурсном плану између номинализације и пасива без агенса.

Излазећи из сфере граматике, Д. Кликовац о номинализацији говори не само из стилског аспекта већ и из идеолошког, тј., као начину да се означи нечија моћ (стручност, образованост, положај, итд.), као и из утилитарног аспекта, тј. када се њоме таје неке компоненте или се ублажава нека непријатна истина (Кликовац 2008: 183). Ауторка (2008: 186) у закључку истиче и манипулативни потенцијал номинализације да се ,званични говор дистанцира од свакодневног, и да институције изразе своју моћ, и да појединац изгради имиџ образованог и компетентног човека, и да се нека ситуација искаже тако да се неки њени делови прикрију”.

Са позиција системско-функционалне граматике и КАД Мишић Илић $(2011,2018)$ пише о значају номинализације у КАД, илуструјући примерима из српског медијског дискурса. Међу бројним дискурсним и стилским разлозима 
за употребу номинализације уместо сродне, каноничне реченице са субјектом и предикатом, свакако је најзначајније то што омогућава да се избегне не само временска димензија већ и помињање учесника у процесу, посебно агенса, чиме се може замаглити или прикрити његов идентитет и избећи да му се припише одговорност или кривица. Номинализација је стога посебно погодна за изражавање моћи путем мистификације учесника.

2.5. Коментари о дискурсно-функционалној природи номинализације које је дала Кликовац (2008) и осталим конструкцијама у Мишић Илић $(2011,2018)$ послужили су као основа за дискурсне анализе у нашем раду и потврђени су и проширени анализом нашег корпуса. Истичемо да србистичка литература посвећује пажњу структурној анализи и класификацији наведених конструкција, али питање њихове функционалне употребе остаје недовољно обрађено, јер аутори узгредно помињу да су карактеристичније за неки маркиранији функционални стил, попут научног, правног или публицистичког, али нема детаљнијих објашњења о томе када се и како користе у идеолошки обојеном дискурсу и у политичке сврхе, са позиција моћи.

\section{3. СИНТАКСИЧКЕ КОНСТРУКЦИЈЕ ЗА РЕАЛИЗОВАЬЕ ДЕАГЕНТИЗАЦИЈЕ У ИЗЈАВАМА КРИЗНОГ ШТАБА}

\section{1. Корпус}

Синтаксичке конструкције којима се реализује деагентизација проучаване су на ограниченом корпусу изјава које су давали чланови Кризног штаба (КШ). Примери су ексцерпирани из онлајн издања високотиражних дневних новина Телеграф (Т) и Блиц (Б), у периоду од формирања КШ у марту 2020. до октобра 2020. и представљени су или као директни цитати или као индиректни говор, дакле могу се сматрати аутентичним изјавама а не новинарском обрадом. Примери који се понављају у оба извора ексцерпирани су само једном. Из текстова су издвајани примери реченица без агенса, у непосредном језичком контексту, па је тако издвојено 50 краћих језичких сегмената од којих је сваки садржао од један до четири индивидуална примера конструкција, који се понекад могу наћи и у истој реченици. Селектовани примери су подвргнути дескриптивној лингвистичкој анализи, при чему су уочене типичне појавне манифестације. Такође, приликом ексцерпирања примера, нотирани су и подаци о ситуационом контексту, тј. контексту догађаја када је изјава дата, како би послужили у критичко-интерпретативном делу анализе.

Одабрани корпус погодан је за комбиновану анализу из угла синтаксе и КАД јер представља социјално и чак политички релевантан дискурс, који има одлике дисбаланса моћи. КШ, као тело које има велика овлашћења, и за које 
би се у најбољој јавној варијанти могло веровати да поседује одговарајућу стручност, обраћа се преко медија широкој јавности у вези са мерама, одлукама и поступцима предузетим током пандемије, у ситуацији велике кризе која угрожава ту јавност, и здравствено и економски, и на групном и на личном плану.

Одабрани корпус се не може строго подвести под неки функционални стил (према Тошовић 2002). Према извору и сврси, припада публицистичко-информативном стилу, али с обзиром да се директно и индиректно преносе изјаве представника званичног тела Владе РС, може се сматрати да садржи и одлике административног стила комуникације правних лица. Међутим, како чланови КШ наступају и као индивидуе, са позиција ауторитета струке и науке, може се сматрати да они теже и да елементима научног стила покажу своју позицију. Али, истовремено, пошто се јавности обраћају усмено, преко популарних медија, теже да звуче и разумљиво, па се стил изјава може описати и као лични стилизовани образовани разговорни стил. Ипак, имајући у виду примарно извор, сврху и тему комуникације, сматрамо да је корпус најближи комбинацији информативног и административног стила.

Саопштења КШ, као и изјаве појединих његових чланова најпроминентнијих у јавним наступима изазвали су велику пажњу српске јавности, често су коментарисани, и неретко критиковани због нејасноће, непрезицности, недостатка информација, а на крају и отворено због нетачних информација и манипулативности. С обзиром на то да се јавност релативно брзо сукобила са Кризним штабом и кривила његове чланове за прикривање јасних података, за предузимање, односно непредузимање правих мера, као и да је временом КШ све више губио поверење, један од циљева овог рада је да лингвистичком анализом идентификује поступке манипулације језиком, ${ }^{4}$ тј. да се у одређеном типу изјава намерно мистификује агенс. Један од начина да се то постигне су и конкретне синтаксичке конструкције, у комбинацији са лексичким изборима, али и ужи контекст изјаве. Може се претпоставити да би крајњи ефекат употребе таквих конструкција био утисак да КШ (укључујући и представнике Владе у њему) не преузимају кривицу, или се не изјашњавају о томе ко иницира, проузрокује и ко је одговоран за одређене радње или стања у држави у светлу борбе са вирусом.

У тексту који следи дата је квалитативна анализа синтаксичких конструкција деагентизације, илустрована карактеристичним примерима. ${ }^{5}$

${ }^{4}$ Много озбиљније оптужбе на рачун КШ тичу се манипулације бројевима, тј. наводно нетачним и непрецизним (дневним и укупним) информацијама о броју тестираних, оболелих и, нарочито, преминулих особа, али то излази из оквира овог рада.

${ }^{5}$ Навођен је шири сегмент, а примери који су предмет конкретне анализе означени су курзивом. 


\section{2. Пасивне конструкције са партиципским пасивом}

Међу пасивним конструкцијама са партиципским пасивом идентификовано је неколико карактеристичних структурних типова. У два примера у (1) види се употреба најуобичајенијег партиципског пасива, једном са глаголом у перфекту, други пут у футуру.

(1) Гојковић каже да је од почетка сугерисано да су домови за старе слаба тачка, пре свега због старе популације: „Због тога су драстичне мере наложене, али неки су се нажалост оглушили. И сви који су се оглушили о мере и препоруке и законске мере ове државе ће сигурно бити санкuзионсани, ту неће бити попуштања", тврди Гојковић. (Б, 18.04.2020.)

Међутим, занимљивији од морфолошких карактеристика предиката јесте лексички аспект - лексеме наложене и санкционисани. На лексичком нивоу, глаголима који означавају административне и правне принуде, конституише се политичка и правна надмоћ неименованог агенса над народом. Извор моћи је крајње апстрахован и уздигнут на највиши ниво као „мере и препоруке и законске мере ове државе", дакле нешто са чиме нема спора. Комуникативни проблем је јер се говорник позива на ауторитет, а нико не зна о којим се конкретним законским мерама ради нити ко их је тачно и по ком правном основу прописао, и то што се мере и препоруке КШ идентификују са законским обавезама, што је правно неодрживо. На тај начин се ствара осећај несигурности и страха код јавности. Додатно, употреба атрибута са снажним значењем (драстичан) уз именицу мере појачава озбиљност донетих мера. За разлику од два партиципска пасива који означавају радње са позиција ауторитета и моћи (а не каже се да то директно ради КШ, Влада, суд, полиција, на основу конкретног законског прописа), активна форма је јасно искоришћена да се оптуже још увек уопштени кривци за пораст броја оболелих у старачким домовима (неки су се нажалост оглушили). Већ у следећој реченици, оптужба се диже на општији ниво (сви који су се оглушили), уз јасну претњу (биће санкиионисани). Од кога? По ком основу? То остаје нејасно, али је ефекат застрашивања постигнут.

Из лексичког угла, интересантан је пример (2), у којем је употребљен глагол обезбедити у пасиву, у перфекту.

(2) Др Кисић објашњава зашто је важно да се и даље примењују ригорозне мере заштите корисника геронтолошких центара. Она је додала да је у овом тренутку позитивно 38 корисника социјалних установа, као и 10 запослених: „Мала је вероватноћа, посебно с обзиром на то да долази хладније време, јесте да се мере релаксирају. Међутим, обезбеђене су вакцине против сезонског грипа и стрептококе која изазива пнеумонију.” (Т, 09.10.2020.) 
Значење глагола упућује на то да се преноси информација да постоје одређена средства, али његовом пасивном формом, као и изостајањем експлицираног агенса у реченицама остаје нејасно ко је обезбедио вакцине. Заправо, недостатак било каквих конституената који би директно одређивали предикат неким околносним значењем појачава ефекат намерног прикривања извора набављених средстава као и када ће доћи до оних којима су потребна. ${ }^{6}$

Структурно, у конструкцији са партиципским пасивом, издвајају се оне код којих је у функцији субјекта читава зависна клауза, и то изрична, у финалном положају у реченици. Ове конструкције се могу сматрати пасивним јер постоји слагање транзитивног глагола и субјекта, а могућ је и тест супституције клаузе заменицом у акузативу (Обећано је то). Семантички, партиципи означавају глаголе вербалне комуникације (нпр. сугерисано је, констатовано је, обећано је, закључено је). Такав пример се може видети у првој реченици у (1) и у (3).

(3) Министар Лончар је поводом прозивки да су тачни подаци о броју умрлих прикривани истакао: Обећано је да ће ревизија бити урађена. (Б, 01.10.2020.)

У (3) примећујемо комбинацију пасивних конструкција, при чему предикат управне реченице представља глагол обећати у пасиву, у перфекту, а предикат изричне реченице је глагол урадити у пасиву, у футуру I. Њихова комбинација наводи на тумачење да је прикривен агенс који изводи чин обећавања, а пасивом у футуру 1 је постигнута и неизвесност извршења саме радње.

Нађен је и један пример са пасивном конструкцијом у којој је субјект, односно пацијенс особа која говори - (4).

(4) Нови Пазар јесте град са највећом стопом морталитета и највећим леталитетом када је у питању ковид-19. Нисам упозната са тачним бројевима о укупној смртности. У Новом Пазару имамо највећи број умрлих особа у односу на број становника као и у односу на број лабораторијски потврђених особа - казала је др Кисић Тепавчевић

\footnotetext{
${ }^{6}$ Иако то није био непосредни предмет анализе, у додатном контролном корпусу чланака и изјава на тему ковид-19, партицип пасива обезбеђен најчећше је нађен у изјавама Председника Србије, нарочито на почетку пандемијске кризе марта 2020. Типичне су две изјаве од 17.03.2020, пренете у медијима: „Вучић је истакао да у Србији много мање недостаје потребних ствари него, на пример, у земљама ЕУ и САД: „Код нас недостају дезинфекциона средства и тренутно немамо довољне количине хируршких маски, али су обезбеђене и биће их у огромним количинама."

„Имамо сада и много више респиратора и то не само у односу на 2009. и 2013. већ и у односу на пре седам дана. Стиже много већи број респиратора”, објашњава председник. „Имамо и транспортне респираторе, који су важни, поред клиничких респиратора, а обезбеђени су и потребни гасови."
} 
поводом питања да образложи нагло погоршану ситуацију у Новом Пазару. (T, 30.07.2020.)

Мотивација за употребу пасивне конструкције у односу на канонични актив јесте не само стилске природе, већ би се могло рећи и идеолошке, да говорница себе представи као високостручну и професионалну, али и да сваку одговорност скине са себе, макар то била само и одговорност за прибављање тачних информација. Званични административни стил у саопштавању непријатних истина наглашен је именицама латинског порекла и номинализацијама: стопа морталитета, највећи леталитет, тачни бројеви о укупној смртности. Уколико би докторка употребила активну форму Не знам и себе ставила у положај агенса, то би не само имплицитно указало на њену одговорност већ би и стилистички административна фраза „тачни подаци о укупној смртности", деловала стилистички инкомпатибилно, у односу на уобичајено и јасно речено Не знам тачан број умрлих, с тим што у пасиву бити упознат има нешто блаже значење од глагола знати, па говорник као да себе жели да стави у улогу пацијенса, а не агенса.

\section{3. Пасивна конструкција са рефлексивним пасивом}

Иако није рађена квантитативна анализа, примећено је да су примери рефлексивног пасива најбројнији у корпусу, што може да укаже да је ова конструкција преферентан избор када је намера говорника да искаже јачу имперсонализацију, јер је у тим конструкцијама углавном онемогућено додавање агенса на синтаксички начин, те је и то погодна карактеристика за избор ових конструкција у циљу намерног скривања агенса, и манипулације. ${ }^{7}$

Примери који илуструју конструкције са рефлексивним пасивом у чијем је саставу сложени предикат са модалним глаголом посебно су упечатљиви јер су модални глаголи често употребљени у значењу налога, препоруке или забране (морати, моћи, треба), при чему се употребом пасива без агенса постиже ефекат дистанцирања саговорника од издавања датих налога, или предлога, али и од сопствене немогућности да се на неки исход утиче.

(5) Највећи број заражених је у Београду, мере се морају пооштрити. Очекује се пораст броја заражених ковидом, али да својим понашањем покажемо да то не мора да се деси. Добра вест је да поштовање превентивних мера уједно представља и превенцију за грип - Кисић наводи као оправдање за пооштравање мера. (Т, 07.10.2020.)

${ }^{7}$ Слично запажање о фреквентности и манипулативној употреби рефлексивног пасива у румунском, на корпусу говора Н. Чаушескуа даје Илие (1998). 
Употребљен је глагол морати који има јаче облигаторно значење од нпр. глагола треба. Међутим, сама употреба тог глагола може уједно бити и изражавање присиљености да се изврши нека радња, под притиском неких спољашњих фактора на које се не може утицати. Да је реченица у активу: Морамо пооштрити мере, опет је ублажена директна одговорност КШ који ту акцију мора предузети, јер се ограђује употребом модала који претпоставља наметнутост те обавезе. С друге стране, намера да КШ пооштри мере још је ублаженија рефлексивним пасивом, а опет је употребом презента остварена и актуелност и ургентност радње. Када би се употребио партиципски пасив уместо рефлексивног (Морају да буду пооштрене), поред тога што се у том случају синтаксички може додати агенс (од + (стране) Ген.), презент глагола бити више упућује на неку будућу радњу и ургентност је слабија.

Примери у футуру имају и додатно тумачење неостварености радње, с обзиром на то да је то радња која је само планирана, а притом није додатно спецификована временским детерминаторима, што се види у примерима у (6). У другој реченици је чак модални глагол тај који је у форми рефлексивног пасива и футура 1.

(6) „Полазак у школу је најзначајније питање сада. Данас смо добили допис од Министарства. Неке ствари су добро процењене од самих просветара. Замисао је једна ствар, а спровођење друга. Нисам спреман да одговорим како ће се то спроводити, а питање о маскама ће такође морати да се дискутује. Није једноставно доносити одлуке о том питању" - одговорио је Кон у вези са поласком деце у школу. (Б, 03.08.2020.)

У (7) употреба пасива у обе клаузе додатно појачава дистанцирање агенса од извршења радње и преузимања било какве одговорности.

(7) Др Кисић је, говорећи о Дому за смештај старих особа у Великом Поповцу, који се огласио да им је потребна помоћ, изјавила: „Потребан је и већи број здравствених радника да прате стање људи тамо. Учиниће се све да се колегама тамо помогне". (Б, 04.08.2020.)

И са рефлексивним пасивом, као и са партиципским (примери 1 и 3), нађене су конструкције где је субјекат цела зависна изрична клауза у финалној позицији - пример (8). Семантички, ови глаголи се разликују од партиципских пасива и означавају когнитивне а не вербалне радње. Употребом пасива и одсуством експлицираног агенса, али и присуством клауза уместо нижих синтаксичких јединица у улози пацијенса, остварује се ефекат додатног дистанцирања агенса од радње. 
(8) „Очекује се да ослаби потенцијал преношења заразе” - рекао је проф. др Предраг Кон на конференцији за медије на тему о наставку борбе са корона вирусом, у сусрет другом таласу епидемије, као одговор на питање да ли ће вирус прећи и на осетљиве групе. (Т, 29.05.2020.)

Примери употребе рефлексивног пасива илуструју имперсонализацију и прикривање агенса, и мада се полази од претпоставке да је агенс иза изјава заправо КШ, који спроводи мере и радње, сама употреба пасивне уместо активне конструкције оставља јак утисак да тај исти агенс жели да остане у сенци док се спроводе поступци, како због опрезности какву ће реакцију ти поступци изазвати у јавности тако и због неизвесности остваривања обећаног.

\section{4. Обезличене реченице}

Безличне конструкције су погодне за деагентивизацију, јер се њиховом употребом намеће уопштени агенс, али их је у корпусу нађено мање него пасивних. За разлику од пасива, у безличним реченицама често изостаје информација о пацијенсу као директном трпиоцу радње, те је њихова информативност комплетнија тек кад је пацијенс исказан преко неправог објекта, и то често као номинализована конструкција.

(9) „Није време да се разговара о укидағу мера” - одговорио је Кон поводом спекулација да ће ванредно стање бити укинуто због пада броја заражених. (T, 01.05.2020.)

Глагол у зависној клаузи је непрелазан и у 3. л. ј. ср. рода (безлични облик). Међутим, индиректна објекатска допуна је предлошко-падежна конструкција, у оквиру које постоји номинализација. Поред тога, управна клауза такође носи обележје безличности јер је егзистенцијална. Када се целокупно сагледа ова безлична конструкција, бројни синтаксички поступци су играли улогу у потискивању агенса, а са лексичке стране, реч је о глаголу разговара$m u$, који подразумева учешће најмање два агенса у тој радњи, па су безличном конструкцијом сви потенцијални агенси замагљени.

\section{5. Номинализација}

Примера номинализације, али и декомпоновања са девербативном именицом најчешће има у комбинацији са пасивним конструкцијама, или пак са другим примерима номинализације. Тада се постиже и најјачи ефекат имперсонализације исказа.

Пример више пута у корпусу нађене глаголске именице је синтагма попуштање мера, а један пример употребе видимо у (10). 
(10) „Дневна бројка новозаражених одраз је нашег понашања од nопуштања мера после Ђурђевдана до данас, што се односи и на понашање грађана и рад у колективима" - одговорио је Тиодоровић на питање да ли су пожурили са попуштањем мера, имајући у виду пораст заражених. (Б, 20.05.2020.)

Ова синтагма кондензује временску реченицу са глаголом у перфекту, jep је у питању прошла радња. Међутим, номинализацијом је заобиђен агенс, иако је познат саговорницима, али је зато занимљиво како је у истој реченици дистанца са агенсом у тој конструкцији појачана, а потом смањена у синтагми нашег понашања јер говорник укључује себе и саговорнике сада као вршиоце радње. Међутим, то је такође само стратегија ублажавања преношења директне кривице, јер већ у релативној реченици он се помињањем грађана и колектива ограђује (у име Штаба) од одговорности.

Деагентивност номинализације види се у изјави (11) у којој нема тако јаке конотације намерног скривања одговорности, али зато има утилитарну функцију ублажавања евентуалних непријатних истина (Кликовац 2008):

(11) „Још нисмо изашли из ситуације која је неповољна. Постоји бојазан да ће се ситуација погоршати, али и нада да ће се поправити у исто време" - навео је Срђа Јанковић након седнице на којој су донели меру забране окупљања за више од десет особа. (Т, 09.05.2020.)

Конструкција постоји бојазан пример је декомпоновања са девербативном именицом у номинативу, тј. у субјекатској функцији, а цела клауза је уједно и егзистенцијалног карактера, што јој даје и призвук безличне конструкције. Зависна реченица која се надовезује на ову конструкцију је такође значајна, јер је именица ситуација еуфемистички термин којим се елидирају детаљи оног што она подразумева, а поготову јер нема никакве детерминаторе. И док је први део комуникативне реченице са негативном, али ублаженом информацијом, други лексички јесте супротан, али је на истом нивоу у погледу ублажености, те се постиже равнотежа. Оно што се оваквом конструкцијом постиже јесте ограђивање од личних и јаких тврдњи, које би биле много очигледније да су речене у активу: Бојимо се да се ситуаиија може погоршати, али надамо се да се може и поправити. У номиналној конструкцији лични став остаје прикривен.

\section{6. Комбинација конструкција}

Како је већ истакнуто, у анализираним сегментима често је било више од једног примера употребе неке од посматраних синтаксичких конструкција, а у неким случајевима више од једне конструкције било је и у оквиру исте 
реченице. Неколико примера комбинације конструкција завређује посебан коментар, а од значаја су морфолошки, лексички, синтаксички и дискурсни аспекти. Може се сматрати да изјаве у којима има више од једне конструкције, било да су у истој комуникативној реченици, или се две комуникативне реченице надовезују, указују да доследна употреба неканоничних конструкција може упућивати на намерни, свесни избор са неким циљем.

Погледајмо још једном пример (3), овога пута без контекста, као пример (12):

(12) Обећано је да ће ревизија бити урађена. (Т, 01.10.2020.)

Независна клауза је комбинована са изричном реченицом која се може сматрати постпонованим субјектом пасивне реченице са семантичком улогом пацијенса. Морфолошки, обе клаузе садрже партиципски пасив глагола у свршеном облику. Перфекат у првој клаузи упућује на завршену и остварену радњу, а футур 1 у другој реченици може имати и временско и модално значење (Танасић 2005, Клајн 2005). Футуру 1 који је везан за референтну тачку у прошлости приписује се релативно значење, али с обзиром на то да лексичко-семантичка карактеристика глагола управне реченице упућује на његову перформативност речима, а не радњом, онда се и испуњеност радње футура 1 доводи у питање, па му се може приписати и модално значење, тј. изражавање става према радњи. Потом, постоји и девербативна именица ревизија, а читава конструкција са глаголом урадити представља облик декомпоновања, који је притом и у пасиву. Одсуство било каквих темпоралних одредница везаних уз један или други глагол такође упућује на непрецизност радњи на стварној временској оси. И поред тога, ужи контекст је тај да Министар здравља и члан КШ, који изговара ову комуникативну реченицу, одговара на прозивке јавности да КШ није давао тачне податке о броју умрлих и заражених. Овим вишеструким онемогућавањем присуства агенса у конструкцијама у датом контексту постиже се дистанцирање говорника од одговорности за испуњење обећања, али и од детерминисања правог агенса.

С друге стране, нешто је слабији ниво блокирања агенса у комбинацији где су две пасивне конструкције, двеју клауза у координантном односу, где прва клауза не утиче на тумачење друге као у зависном односу, већ су паралелне.

(13) Др Кисић Тепавчевић је, говорећи о почетку школске године, навела да је данас било речи о прављењу најоптималнијег модела за похађање школске наставе за децу: „Разматран је сваки појединачни модел, донеће се оно решење које ће представљати најмањи могући ризик за ширење епидемије корона вируса.” (Т, 07.08.2020.)

Перфекат у првој клаузи је у несвршеном облику, што може говорити о незавршености и незаокружености радње, док је футур 1 у свршеном облику, али је такође и рефлексивни пасив, те ова комбинација не само да упућује на 
радњу која још није извршена већ је и агенс још мање могуће реконструисати него код пасива са партиципом. Самим тим да контекст даје увид да ће било каква одлука имати пресудну улогу у заустављању вируса, може се рећи да ове конструкције и по својој структури и по контексту више упућују на уздржаност и ублажавање одговорности агенса, који је управо сам КШ. У овом сегменту примећује се и јак административни стил, уз гомилање глаголских именица у саставу генитивних синтагми.

Добар пример потпуног дистанцирања од доношења одлуке и преузимања одговорности, а самим тим и кривице за последицу предузетих мера представља изјава (14). У њој постоји комбинација двеју номинализација:

(14) „У том случају је потребна велика опрезност код доношења одлу$\kappa e "$ - навео је Кон поводом питања да ли ће Штаб уважити захтеве угоститеља да одрже музичке манифестације. (Т, 28.09.2020.)

Прва именица је деадјективна и налази се у декомпонованој конструкцији са глаголом бити и придевом потребан. Придев је девербативан, а и сама употреба придева са основом глагола требати, који је безличан у модалном значењу, додатно појачава имперсонализацију. Потом, номинални члан те конструкције је деадјективна именица, са атрибутом интензификатором велики. Адвербијално околносно значење садржи се у кондензованој конструкцији $к о д+$ Ген. глаголска именииа + Пос. ген. девербативна именица. Овом конструкцијом поново је избегнуто наглашавање агентивности у тој радњи, а комбинацијом обеју конструкција стиче се изузетно јак утисак дистанцирања од агенса поводом предузимања било каквих пресудних одлука, не би ли се избегло преузимање кривице за потенцијалне негативне исходе преузетих мера.

\section{4. ЗАКљУЧАК}

У раду је разматрана дискурсна стратегија деагентизације и синтаксичке конструкције којима је реализована у корпусу изјава у медијима чланова КШ поводом пандемије вируса ковид-19. Уз дескриптивну формално-текстуалну анализу, примери су интерпретирани и у светлу критичке анализе дискурса, јер су и саме изјаве а и догађаји од друштвеног и политичког значаја. КАД инсистира на томе да се у анализи друштвено и политички релевантног дискурса не анализирају само језичке структуре већ и дискурсне стратегије као вербалне радње, чији је циљ да се утиче на читаочеву представу о друштвеној стварности. Комбинованом структурном, семантичком и критичко-дискурсном анализом описане су специфичности употребе неколико неканоничних синтаксичких конструкција у српском језику (партиципски пасив, рефлексивни пасив, обезличене конструкције, номинализација). 
Идентификовано је више различитих, понекад истовремених функција деагентизације. Осим најопштије анонимизације агенса, постиже се и представљање радњи као стања и неспорних чињеница, нарочито у комбинацији пасива са деонтичким модалима. Деагентизација мистификује не само учеснике у процесима већ и уклања временску компоненту. Уколико је реч о радњама које (треба да) предузимају представници КШ и конкретни органи власти, деагентизацијом се и умањује лична одговорност, али и делегирано присваја моћ од виших ауторитета („наша држава/влада”). Деагентизација је и одлика административног номиналног стила који користе представници КШ, а којим додатно делују са позиција ауторитета и наметања (суптилних) претњи и страха. Општи закључак је да примери највише показују извесну уздржаност саопштавача да јасно прецизирају ко је предузимао или ће предузимати одређене мере и поступке, те се ствара сумња у поузданост свих тих поступака и у сигурност стручњака. Анализа показује да су овакве језичке стратегије ипак суптилне, али врло ефектне и да, иако дискурс није у потпуности својствено политички, јер се дотиче здравства и општег јавног интереса, ипак је у ту сврху политизован и неопходно је приступати му критички.

Одступање од каноничних конструкција (активне реченице, глаголи уместо номинализација за исказивање радње) представља језичко енкодирање у смислу прерасподеле семантичких улога, конкретно, избегавање агенса. Оно и рефлектује говорникову перспективизацију процеса (радњи, стања) о којима говори, а коју намеће јавности којој се обраћа. Харт (2014: 2) овакву перспективизацију сматра идеолошком, а и сам језик идеолошким када се користи да промовише једну перспективу у односу на друге и кроз лексичке и структурне опције нешто прикаже на различите начине. Анализом језика може се указати на идеолошке изборе у дискурсу - језички систем може да служи као референтни оквир да се упореди оно што је исказано са оним што је потиснуто и да се упореди начин како је нешто исказано у конкретном тексту са другим могућим опцијама у језичком систему. Управо смо у својој анализи и пробали да поредимо употребљене неканоничне конструкције са њиховим каноничним верзијама.

Избор посматраних неканоничних опција свакако није само стилска одлика административног или информативног функционалног стила већ и сам такав стил у обраћању стручњака КШ широј јавности указује на наметање одређене перспективе. Она се тиче како самих процеса/догађаја о којима је реч тако и перспективе друштвених односа, где постоји несразмера између знања, информација и моћи, у корист представника власти оличених у КШ, у односу на јавност, тј. обичан народ. Деагентизација постаје не само синтаксичка опција и дискурсна стратегија већ и средство којим се народу шаље суптилна идеолошка порука, поспешује даље отуђење, неповерење и страх створен нејасним информацијама и претњама, али и резигнација и пасивизација јавности. 


\section{ЛИТЕРАТУРА}

Батстон 1995: R. Batstone, Grammar in discourse: attitude and deniability, in G. Cook G., and Seidlhofer B. (eds.), Principle and Practice in Applied Linguistics, Studies in honour of H. G. Widdowson, Oxford: OUP, 197-214.

Белај 2002: B. Belaj, Nominalizacija kao strategija pasivizacije, Suvremena lingvistika, 28/53-54, 11-26.

Ван Лувен 2008: T. Van Leeuwen, Discourse and Practice: New Tools for Critical Discourse Analysis, Oxford: Oxford University Press.

Видовсон 2007: H. G. Widdowson, Discourse Analysis, Oxford: OUP.

Вилсон 2003: J. Wilson, Political Discourse, in Schriffin, D., Tannen D. and Hamilton, H. (eds.) The Handbook of Discourse Analysis, Oxford: Blackwell Publishing, 398-415.

Водак 2001: R. Wodak, The Discourse-Historical Approach, in Wodak, R. \& M. Meyer, (eds.) Methods of Critical Discourse Analysis, London: Sage Publications, 63-94.

Илие 1998: C. Ilie, The Ideological Remapping of Semantic Roles in Totalitarian Discourse, or, How to Paint White Roses Red. Discourse \& Society 9, 57-80.

Клајн 2005: I. Klajn, Gramatika srpskog jezika, Beograd: Zavod za udžbenike i nastavna sredstva.

Кликовац 2008: Д. Кликовац, О стилским, идеолошким и утилитарним аспектима номинализације у српском језику, Јужнословенски филолог, LXIV, 177-188.

Кранерт и др. 2020: M. Kranert et. al, COVID-19: The World and the Words.: Linguistic means and discursive constructions, DiscourseNet Collaborative Working Paper Series, no. 2/9, Special Issue: Discourse Studies Essays on the Corona Crisis, https://discourseanalysis.net/ dncwps.

Мишић Илић 2011: Б. Мишић Илић, Синтакса у критичкој анализи дискурса: о неким конструкцијама за исказивање и скривање идентитета, Српски језик, XVI, 91-107.

Мишић Илић 2018: В. Mišić Ilić, Agentivnost u medijskom diskursu, u J. Petković, V. Polomac (ur.) Srpski jezik, status, sistem, upotreba. Zbornik radova u čast prof. Milošu Kovačeviću, Kragujevac: FILUM, 445-461. 
Московљевић Поповић 2018а: Ј. Московљевић Поповић, Глаголи типа владати у имперсоналним конструкцијама с партиципским пасивом у савременом српском језику, Анали Филолошког факултета, XXX/1, 169-184.

Московљевић Поповић 2018б: Ј. Московљевић Поповић, Глаголи комуникације и когнитивних процеса у имперсоналним конструкцијама с партиципским пасивом, у Ј. Петковић, В. Поломац, (ур.), Српски језик: статус, систем, употреба. Зборник у част проф. др Милошу Ковачевићу, Крагујевац: ФИЛУМ, 235-246.

Мразовић/Вукадиновић 2009: P. Mrazović, Z. Vukadinović, Gramatika srpskog jezika za strance, Beograd: Zavod za udžbenike.

Пипер и др. 2005: П. Пипер, И. Антонић, В. Ружић, С. Танасић, Љ. Поповић, Б. Тошовић, Синтакса савременога српског језика: проста реченица, (ред. академик Милка Ивић), Београд: Институт за српски језик САНУ, Београдска књига; Нови Сад: Матица српска.

Радовановић 1990: M. Radovanović, Spisi iz sintakse i semantike, Sremski Karlovci: Izdavačka knjižarnica Zorana Stojanovića; Novi Sad: Dobra vest.

Саведра 2009: D. Saavedra, Deagentivnost sintaktičkih konstrukcija u hrvatskome jeziku, Suvremena lingvistika 67, 69-85.

Саведра 2010: Д. Сааведра, Пасивне конструкције с партиципом и с повратним обликм глагола у српском језику - конкуренција и допунска дистрибуција, у М. Ковачевић (ур.) Језички систем и употреба језика, зборник радова, Крагујевац: Филолошко-уметнички факултет, 81-94.

Станојчић/Поповић 2002: Ж. Станојчић, Љ. Поповић: Граматика српског језика, Београд: Завод за уџбенике.

Танасић 2005: С. Танасић, Синтаксичке теме, Београд: Београдска књига.

Танасић 2014: С. Танасић, Синтакса пасива у савременом српском језику, Београд: Београдска књига.

Танасић 2018: С. Танасић, Безличне партиципске реченице у српском језику, Српска славистика: колективна монографија. Том 1, Језик, Радови српске делегаиије на XVI међународном конгресу слависта, Vol. 1: 28, 407-423.

Тошовић 2002: Б. Тошовић, Функиионални стилови, Београд: Београдска књига.

Ферклаф 1992: N. Fairclough, Discourse and Text: Linguistic and Intertextual Analysis within Discourse Analysis. Discourse \& Society 3 (2), 193-217. 
Ферклаф 1995: N. Fairclough, Critical Discourse Analysis, Boston: Addison Wesley. Ферклаф 2001: N. Fairclough, Language and Power, 2nd ed., London: Longman. Харт 2014: C. Hart, Discourse, Grammar and Ideology: Functional and Cognitive Perspective, London: Bloomsbury Academic.

\section{ИЗВОРИ}

Изјаве су преузете из архиве онлајн издања Телеграфа и Блица у вези са Кризним штабом у периоду од средине марта до октобра 2020.

Телеграф (Т) https://www.telegraf.rs/teme/krizni-stab

Блиц (Б) https://www.blic.rs/krizni-stab

\section{DEAGENTIZATION IN THE STATEMENTS OF THE CRISIS STAFF REGARDING THE COVID-19 PANDEMICS IN SERBIA}

\section{Summary}

The article deals with the discourse strategy of deagentization in the statements of the Crisis Staff, as reported in the Serbian media regarding the Covid-19 pandemics in Serbia. The article investigates how deagentization is realized by the use of several syntactic constructions (agentless passives, impersonal constructions, nominalization). The qualitative analysis of the examples examines not only the possible correlations between syntactic and lexical choices, but also the discursive context that determines the choice and combination of language devices. The results can be interpreted in the light of the Critical Discourse Analysis as a discursive strategy of deagentization, that is, the conscious and conventional choices of language constructions and their combinations aimed at mystifying and manipulating the public in the particularly sensitive social circumstances.

Key words: Critical Discourse Analysis, agentivity, deagentization, passivization, nominalization, impersonal constructions, Serbian, Crisis Staff. 